Int. J. Electrochem. Sci., 15 (2020) 12410 - 12419

\title{
Effect of Sugarcane Bagasse Ash and Ceramic Waste Dust as Partial Replacements of Portland Cement on Corrosion Behavior of HRB400 Low Carbon Steel Reinforcement in $3.5 \%$ $\mathrm{NaCl}$
}

\author{
Yigang Yang ${ }^{1}$, Weibing Luo ${ }^{2, *}$ \\ ${ }^{1}$ College of Architectural Engineering, Jiangxi Vocational College of Finance and Economics, \\ Jiujiang, 332000, China \\ ${ }^{2}$ School of Civil Engineering and Architecture, East China Jiaotong University, Nanchang, 330013, \\ China \\ *E-mail: bgpyyg@126.com, jxlwb00@163.com and yangyigang6666@ 163.com
}

doi: $10.20964 / 2020.12 .29$

Received: 8 August 2020 / Accepted: 24 September 2020 / Published: 31 October 2020

\begin{abstract}
Nowadays corrosion protection of reinforced concrete can be increased by improving the concrete structure, particularly the replacement of cement by mineral additives. In this study, the influence of a partial replacement of Portland cement (PC) on the corrosion behavior of HRB400 carbon steel rebar in $3.5 \% \mathrm{NaCl}$ solution was considered. The PC was replaced by a mixture of bagasse ash (BA) and ceramic waste dust (CWD) admixtures. The mechanical results indicated an increase in compressive strength for BCWD concrete samples containing both BA and CWD additives. The electrochemical findings indicated that the BCWD sample has considerably improved the structure of concrete as well as decreased corrosion resistance due to the decrease of water permeability and chloride ion. Scanning electron microscopy of the steel surface exhibited that the concrete structure including BA and CWD additives was more uniform and denser compared to the PC sample which was in agreement with electrochemical results.
\end{abstract}

Keywords: Electrochemical corrosion behavior; Partial replacement; HRB400 carbon steel; Compressive strength

\section{$\underline{\text { FULL TEXT }}$}

(C) 2020 The Authors. Published by ESG (www.electrochemsci.org). This article is an open access article distributed under the terms and conditions of the Creative Commons Attribution license (http://creativecommons.org/licenses/by/4.0/). 